\title{
Evaluation of mechanical properties of teak sawdust and PVC wood plastic composite
}

\author{
B. Latha Shankar ${ }^{*}$, R.N. Darshan ${ }^{2}$, Sagar B. Sansuddi ${ }^{3}$, S. Aditya ${ }^{4}$ \\ ${ }^{1 *}$ Department of Industrial Engineering and Management, Siddaganga Institute of Technology Tumkur, INDIA \\ ${ }^{2,3}$ Department of Mechanical Engineering, Siddaganga Institute of Technology Tumkur, INDIA \\ ${ }^{4}$ Prabitha polymers, Challakere, INDIA \\ *Corresponding Author: e-mail: blathashankar@yahoo.com, Tel +91-9964505469 \\ ORCID iD: https://orcid.org/ 0000-0003-3516-9319 (Latha Shankar), ORCID iD: https://orcid.org/ 0000-0002-9850-8149 (Darshan), ORCID iD: \\ https://orcid.org/0000-0001-5750-2309 (Sansuddi), ORCID iD: https://orcid.org/0000-0002-1897-0086 (Aditya)
}

\begin{abstract}
Wood plastic composites (WPC) are becoming popular in recent years, in majorly automobile and building sectors due to their attractive properties and sustainability compared to traditional materials. This work focuses at mechanical property evaluation of WPCs made of teak wood flour (wastes obtained from wood cutting mills), Poly Vinyl Chloride (PVC) and Calcium Carbonate as major ingredients. Fabrication of WPC is done using the extrusion process. Tensile, compressive, bending and impact tests were carried out as per ASTM standard testing method D 4761-19 to evaluate mechanical properties of the WPC. It was found that above said WPC has tensile strength of $7.69 \mathrm{~N} / \mathrm{mm}^{2}$, compression strength of $11.42 \mathrm{~N} / \mathrm{mm}^{2}$, flexural strength of $15.264 \mathrm{~N} / \mathrm{mm}^{2}$ and impact strength (Izod) of $0.265 \mathrm{~N}-\mathrm{M} / \mathrm{mm}^{2}$. From these mechanical properties of proposed PWC, it can be concluded that it can replace natural wood, when mechanical performance requirements are within above mentioned allowable values and where seasonal affect, humidity, moisture absorption etc. are the major problems. Additionally since wood waste is used in proposed PWC, material is considered more sustainable and eco-friendly.
\end{abstract}

Keywords: WPC, PVC, Teak saw dust, Extrusion, ASTM, sustainable

\section{Introduction}

Wood Polymer Composites (WPC) are increasingly being used in modern construction segment since four decades. WPC is an example for bio-based material, and hence need of the day (Carus \& Dammer, 2013, Dahman \& Ugwu, 2014, Friedrich \& Luible, 2015). Making this new material both long lasting and cost-effective is the real challenge for both industry and research. This is because organic components when used as building material, strength of the material is at stake due to water absorption and fungi formation (Clemons, \& Ibach, 2004, Karta et al., 2013). WPCs belong to bio-composite family, fabricated by the blending of wood-based materials and polymers. Wood-based material is in the form of wood fiber/wood flour and polymers are thermoplastics such as Polyethylene/ Polypropylene/ Polyvinyl chloride/Polystyrene etc. It is known that dimensions and organisation of wood based material affect the strength of the WPC (Nourbakhsh et al., 2010). Also various properties of plant fillers used influence mechanical and operational characteristics of composites (Najafi \& Englund, 2013). A study made by Petchwattana et al. (2013) reveals that chemical composition, chemical and physical treatment given to plant fillers play vital role in deciding the chemical characteristics of functional groups of surface fillers. The authors showed that impact strength of the composite is inversely proportional to rice hull content and directly proportional to particle size. Weak interfacial bonding is the major setback for good mechanical performance (Peltola et al., 2014, Chaudemanche et al., 2018, Gulitah et al., 2018). In WPCs interfacial adhesion is enhanced by inclusion of coupling agents. These coupling agents develop an interfacial bond between wood flour and matrix resulting in improved mechanical characteristic (Chotirat, 2007). Maleated polypropylene when used as coupling 
agent upto 3-5 \% by weight for WPC made of recycled polypropylene and Pine wood dust improved interface adhesion and stability (Bhaskar et al., 2012). Research also has evidences that recycled plastics when used as matrix with saw dust have comparable mechanical properties as that of virgin plastics (Poletto et al., 2011, Lee et al., 2003, Singh et al., 2007). High density polyethylene and polypropylene were used as plastics and mixed with beech industrial sawdust separately for the investigation to compare the mechanical properties of virgin and recycled (Najafi et al., 2006). In the presence of appropriate coupling agent composites made of waste polymeric materials and wood fibres show fairly good stability, strength and other mechanical properties (Jayaraman \& Bhattacharyya, 2004). Wood fibres used, being hydrophilic, when treated chemically contribute to enhancement of properties of composites (Gardner et al., 2015).

Many companies have started manufacturing WPCs to be applied for door and window frames sine two decades (Doba, 2001, Bregar, 2001) Though major use of WPC is in building sector, it is also applied for furniture, automobile and packaging (Friedrich \& Luible, 2016). It is reported in research that compared to products made of plastics alone; these composites are of lighter weight, cost-effective and have better acoustic and impact resistance. Compared to other wood based materials, WPC outweighs with respect to maintenance requirement, thermal properties and durability (García et al., 2009).

From above literature review it is evident that not much work has been done on usage of waste wood powder and Calcium carbonate in the fabrication of WPCs. Waste wood powder being renewable resource is an interesting material for research when found being used as construction material. It is an opportunity to convert waste material into useful product for mankind. To explore some more opportunities in this direction, the present work aims to develop cost effective, environment friendly WPCs by making use of waste sawdust powder. Products can be developed to the near net shape using extrusion process thus avoiding secondary machining operations.

\section{Methodology}

2.1 Materials Used: As mentioned earlier WPC is a blend of wood based material and polymer. Teak wood powder of size $50 \mathrm{~m}$ was used as wood based filler and PVC of size $212 \mathrm{~m}$ and calcium carbonate were used as matrix and mineral fillers, respectively. Calcium carbonate was added in order to increase stiffness of composite boards (Klyosov, 2007). Further wax was added as lubricant, $\mathrm{Ca}-\mathrm{Zn}$ as stabilizer, Propylene as impact modifier and Maleic anhydride as coupling agent. The size and amount used as percentage of total weight of various constituents used for composite processing are given in Table 1.

Table 1. PWC constituents and their composition

\begin{tabular}{|l|c|c|c|c|c|c|c|c|}
\hline \multicolumn{1}{|c|}{ Materials } & PVC & $\mathrm{CaCo}_{3}$ & $\begin{array}{c}\text { Wood } \\
\text { powder }\end{array}$ & Wax & $\begin{array}{c}\text { Foaming } \\
\text { agent }\end{array}$ & Ca-Zn & Propylene & $\begin{array}{c}\text { Maleic } \\
\text { anhydride }\end{array}$ \\
\hline Size & $212 \mathrm{~m}$ & $300 \mathrm{~m}$ & $50 \mathrm{~m}$ & $20 \mathrm{~m}$ & $300 \mathrm{~m}$ & $94 \mathrm{~m}$ & $100 \mathrm{~m}$ & $150 \mathrm{~m}$ \\
\hline Percentage used & $50 \%$ & $30 \%$ & $13 \%$ & $1 \%$ & $2 \%$ & $1 \%$ & $2 \%$ & $1 \%$ \\
\hline
\end{tabular}

2.2 Processing of WPC: The important steps in development of WPC include pulverization of PVC, mixing, extrusion, cooling and cutting.

- Pulverization: Pulverizer was used to crush PVC into fine particles of size 212 . It is shown in Figure 1. PVC in the form of granules was poured into a hopper after machine was set as per the requirements.

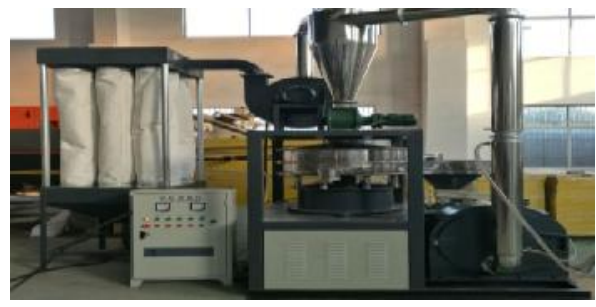

Figure 1. PVC pulverizer

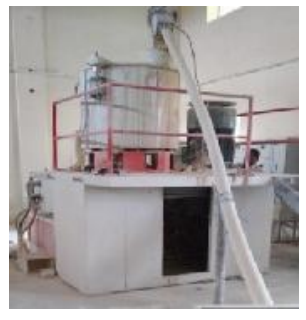

Figure 2. Hot mixer

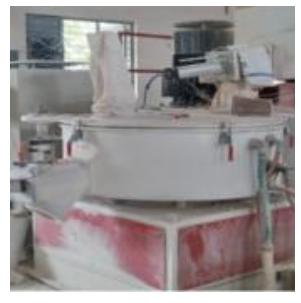

Figure 3. Cold mixer

- Mixing: Mixing or blending is the oldest operation used in the solid based industries to make heterogeneous mixture to homogenous mixture.

○ Hot mixing: In this process all the required raw materials were fed to hot mixing chamber maintained at $110^{\circ} \mathrm{C}$, using the feeding system. In the hot mixing chamber raw materials were melted and mixed thoroughly at a rpm of 350 for $4 \mathrm{~min}$ to form a homogenous paste like mixture The hot mixing equipment is shown in Figure 2.

o Cold mixing: In this process, mixture from the hot mixing unit is transferred to the cold mixing chamber maintained at

ambient temperature and again mixed thoroughly at 350RPM for 3min. This converts the mixture to the amorphous form suitable for the next step called extrusion process. The cold mixing equipment is shown in Figure 3. 
- Extrusion: The raw material required for the preparation of WPC was further fed to the hopper of the extrusion equipment shown in Figure 4. The various temperature levels maintained across the barrel were, feeding zone at $150^{\circ} \mathrm{C}$, Melting zone at $155^{\circ} \mathrm{C}$, Mixing zone at $158^{\circ} \mathrm{C}$ and mould (shown in Figure 5) temperature at $172^{\circ} \mathrm{C}$. These temperature zones help to produce the product with less porosity, good surface finish.

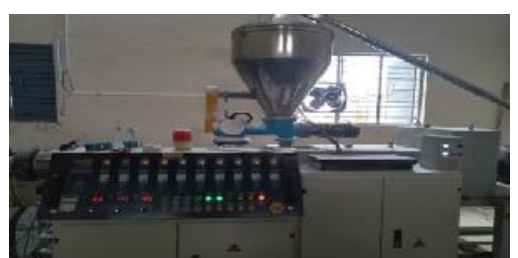

Figure 4. Extrusion equipment

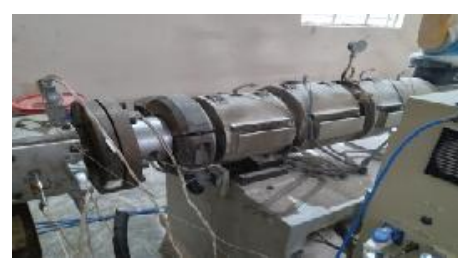

Figure 5. Mould

- Cooling: Extruded part of WPC was hot with a temperature of $170^{\circ} \mathrm{C}$ approximately, making cooling essential. Indirect method of cooling was preferred by maintaining the cold water outside the dies as shown in Figure 6 to achieve the dimensional stability primarily. Later direct method of cooling was adopted by direct contact of water with WPC, to cool to room temperature. Set-up is shown in Figure 7.

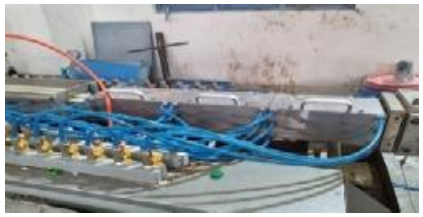

Figure 6. Indirect cooling method

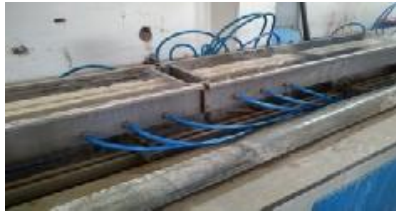

Figure 7. Direct cooling method

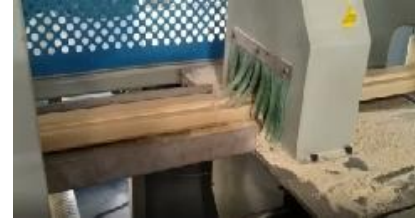

Figure 8. Cutter

- Cutting: Cutting is done to cut the WPC to the desired length based on the requirement of the end user. Cutter is shown in Figure 8 .

2.3 Mechanical testing: Tensile, compressive, flexural and impact tests were conducted to evaluate corresponding mechanical properties. Since this product has majorly PVC and less amount of wood based material, affect of moisture absorption is negligible. All mechanical tests were carried out at room temperature and three replicates for each test were performed. All these tests were conducted as per principles of ASTM standard testing method D 4761-19. This standard is as per the fixed designation D7031-11(2019) (ASTM, 2014).

- Tensile test: To carry out this test, the specimen is prepared as per the ASTM standard and was loaded on UTM. Figure 9 shows the test specimen, Figure 10 shows the testing set-up and Figure 11 tested specimen. Load and displacement values were taken down till fracture of the specimen.
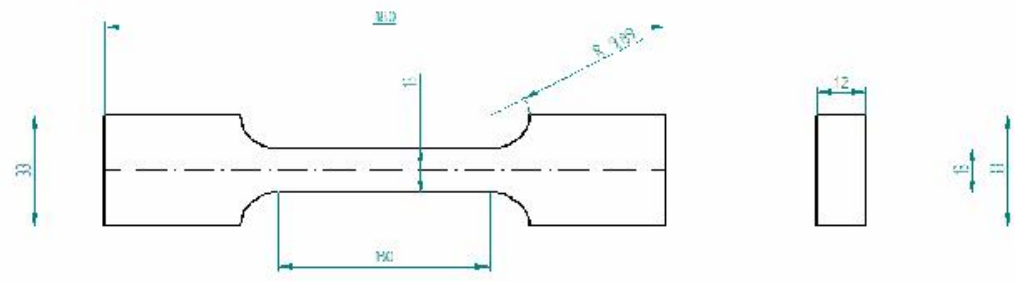

Figure 9. Tensile test specimen.
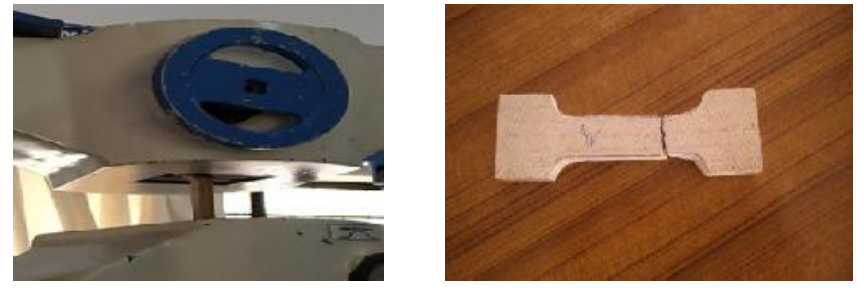

Figure 10. Testing set-up

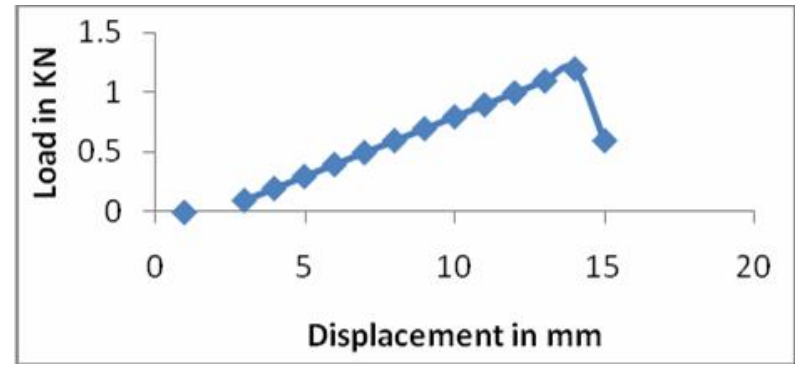

Figure 12. Load v/s displacement 
- Compression test: To carry out this test, compression specimen was prepared according to the standard ASTM D7031 and test was carried out on UTM. Figure 13 shows the compression specimen, Figure 14 shows the testing set-up, Figure 15 tested specimen.

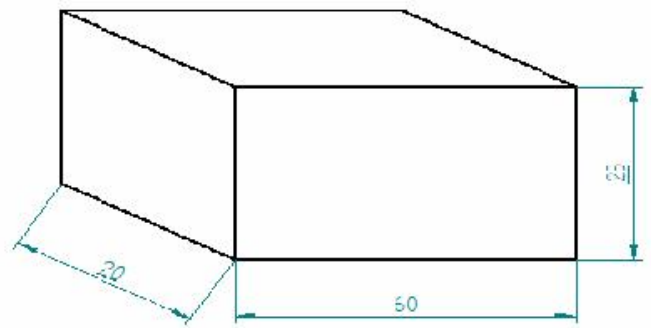

Figure 13. Compression test specimen.

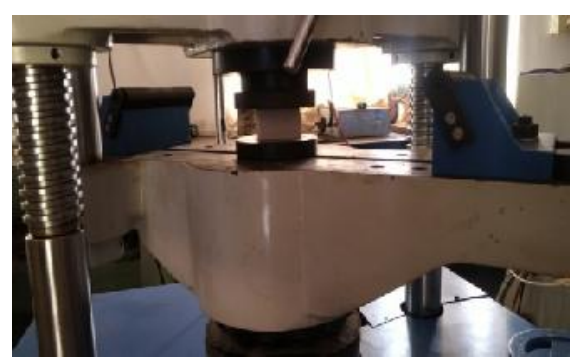

Figure 14. Compression testing set-up

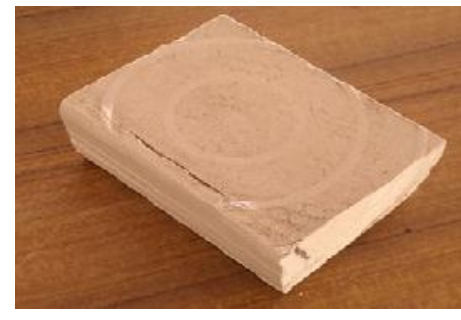

Figure 15. Tested composite specimen

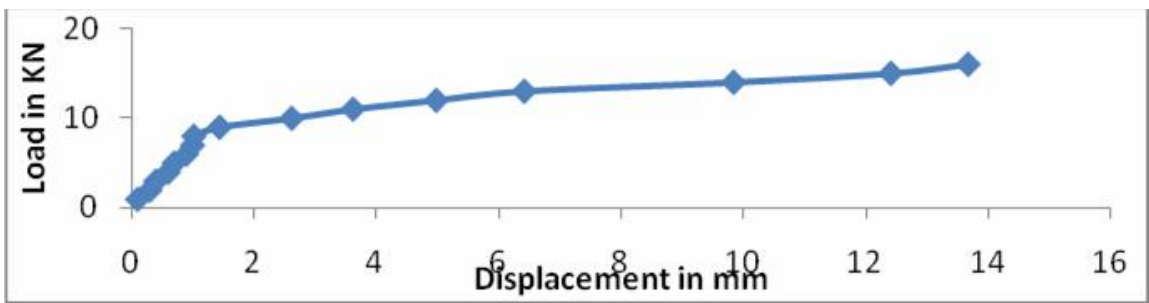

Figure 16. Load v/s displacement

- Bending test: The ASTM standard followed for bending test was ASTM D7031. As per the standard, specimen was prepared. The specimen was loaded on UTM at centre of span at a uniform rate through a loading block. It was found to have $15.264 \mathrm{~N} / \mathrm{mm} 2$ of modulus of rupture. Figure 17 shows the bending specimen, Figure 18 equipment set-up. Figure 19 shows the tested specimen. Various load and displacement values were plotted.

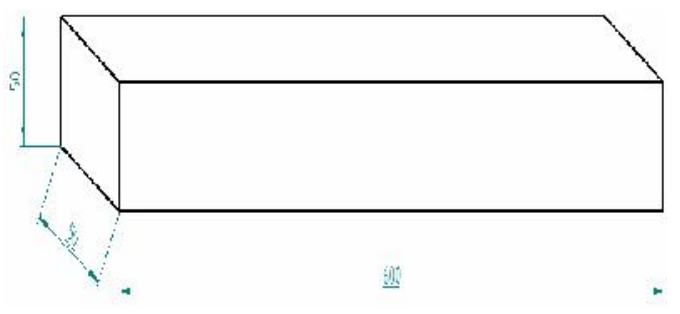

Figure 17. Bending test specimen

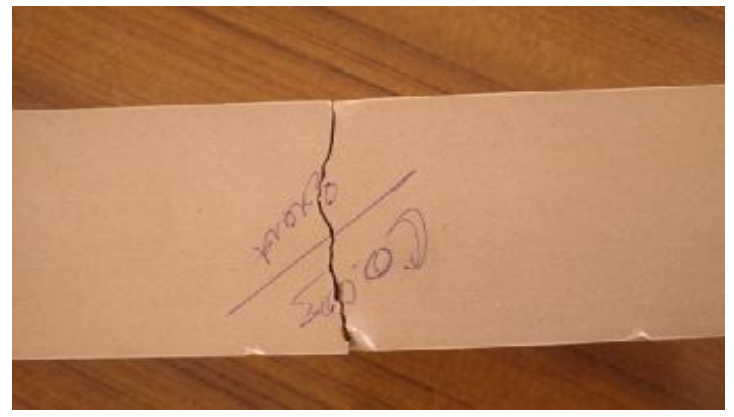

Figure 19. Tested composite specimen

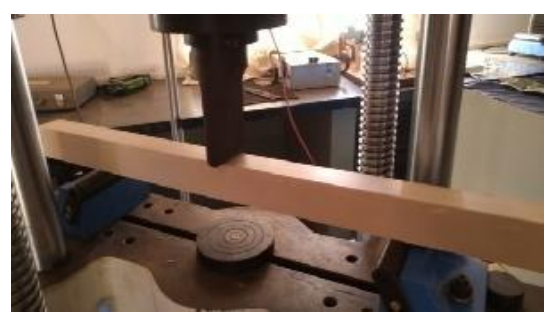

Figure 18. Bending testing set-up

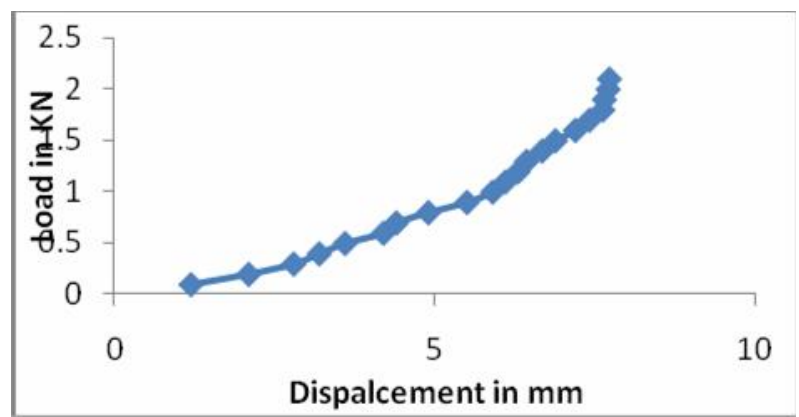

Figure 20. Load v/s displacement 
- Impact test: The Izod test specimen was prepared and the test was carried out in accordance with ASTM standard, and the maximum impact strength was calculated as $0.265 \mathrm{~N}-\mathrm{M} / \mathrm{mm}^{2}$. Figure 21 shows the Izod test specimen as per ASTM standard and Figure 22 equipment set-up.

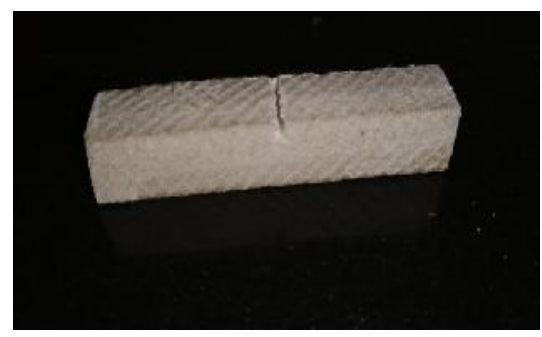

Figure 21. Impact specimen(IZOD)

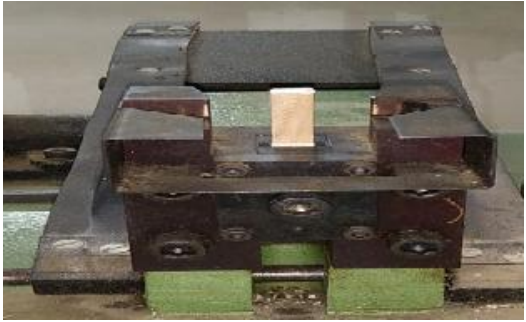

Figure 22. Impact testing set-up

\section{Results and Discussion}

In the present work, mechanical characterization of developed composites was done. Mechanical behavior of the WPCs under static loading of tensile, compressive, flexural and impact were considered. Results are summarized below.

- Figure 12 depicts the load v/s displacement under tensile loading. Maximum tensile strength was found to be $7.69 \mathrm{~N} / \mathrm{mm}^{2}$. The graph shows that the developed composite is not suitable for tensile loading as its ability for toughness is not considerable. Also specimen fails without much yielding and hence susceptible for catastrophic failure.

- Under compressive loading, obtained values of displacement are plotted against load values in Figure 16. Maximum strength in compression was found to be $11.42 \mathrm{~N} / \mathrm{mm}^{2}$. The graph drawn for compressive load vs. displacement indicates that after yielding, the large amount of deformation continues without appreciable increase in load bearing capacity of the specimen. Compared to behavior of the specimen under tensile, compressive loading explores strength of the specimen for real life applications. The large area below the stress-strain diagram signifies the considerable toughness property of the material under compressive loading. This is an indication that material is not vulnerable to catastrophic failure when subjected to compressive loading and hence a good candidate for real life applications where products are subjected to allowable compressive load.

- Figure 20 shows the load v/s displacement under flexural loading. Graph depicts that after yielding, without much strain energy absorption, specimen fails. It may be due to the weak bending strength of the material and when compared, much lower than, the compressive strength of the developed composite.

The results of all above three tests clearly indicate that the developed wood composite may be suitable for structural members under compressive loading, especially door, window panels etc. Also the developed composites have less amount of wood and hence problem of moisture absorption due to environmental influence is negligible. Hence the composite is suitable for adverse environmental conditions where water absorption is a major issue.

\section{Conclusion}

In this work, an attempt is made to convert waste from teak wood cutting mill into useful product to mankind in the form of WPCs. Other major ingredients are Poly Vinyl Chloride (PVC) and Calcium Carbonate. Fabrication of WPC is done using the extrusion process. Ultimate tensile strength, compressive strength, flexural modulus of rupture and maximum impact strength of WPC are determined as per ASTM standard testing method D 4761-19. The results indicate that the proposed WPC is well suited for

- Structural purpose to replace natural wood wherever allowable strength requirements are well within the experimental values mentioned above and seasonal effect is a major issue. Proposed PWC has added advantage over natural wood that it is not influenced by seasonal affect. This is because wood percentage is less in this material and PVC percentage is more.

- Environments where moisture absorption, seasonal effect, humidity are major problems (Ex, coastal areas).

Moreover since wood waste is used in proposed PWC, material is considered more sustainable and eco-friendly.

Further future work can deal with affect of addition of filler materials like short glass fibers, carbon nano-tubes on stiffness and strength of the WPCs.

\section{References}

ASTM International., 2014. Standard guide for evaluating mechanical and physical properties of wood-plastic composite products. ASTM Standard D7031-11. 
Bhaskar J., Haq S., Pandey A.K. \& Srivastava N., 2012. Evaluation of properties of propylene-pine wood Plastic composite. Journal of Materials and Environmental Science, Vol.3, pp.605-612.

Bregar B. Plastic news 2001; Feb 19:1.

Carus M. \& Dammer L., 2013. Food or non-food: which agricultural feed stocks are best for industrial uses? Industrial Biotechnology, Vol.9, No.4, pp.171-176. https://doi.org/10.1089/ind.2013.1580

Chaudemanche S., Perrot A., Pimbert S., Lecompte T. \& Faure F., 2018. Properties of an industrial extruded HDPE-WPC: the effect of the size distribution of wood flour particles. Construction and Building Materials, Vol.162, pp.543-552. https://doi.org/10.1016/j.conbuildmat.2017.12.061

Chotirat L., Chaochanchaikul K. \& Sombatsompop N., 2007. On adhesion mechanisms and interfacial strength in acrylonitrilebutadiene-styrene/wood sawdust composites. International Journal of Adhesion and Adhesives, Vol.27, pp.669-678. https://doi.org/10.1016/j.ijadhadh.2007.02.001

Clemons C.M. \& Ibach R.E., 2004. Effects of processing method and moisture history on laboratory fungal resistance of woodHDPE composites. Forest Products Journal. Vol.54, No. 4, pp.50-57.

Dahman Y. \& Ugwu C.U., 2014. Production of green biodegradable plastics of poly (3-hydroxybutyrate) from renewable resources of agricultural residues. Bioprocess and Biosystems Engineering, Vol.37, No.8, pp.1561-1568. doi: 10.1007/s00449014-1128-2

Doba J. Plastic News 2001; Feb 26:4

Friedrich D. \& Luible A., 2015. Bio-degradable future building skins. In 10th Conference on Advanced Building Skins, pp.14841493.

Friedrich D. \& Luible A., 2016. Investigations on ageing of wood-plastic composites for outdoor applications: A meta-analysis using empiric data derived from diverse weathering trials. Construction and Building Materials, Vol.124, pp.1142-1152. https://doi.org/10.1016/j.conbuildmat.2016.08.123

Garcia M., Hidalgo J., Garmendia I. \& García-Jaca J. 2009. Wood-plastics composites with better fire retardancy and durability performance. Composites Part A: Applied Science and Manufacturing, Vol.40, No.11, pp.1772-1776. https://doi.org/10.1016/j.compositesa.2009.08.010

Gardner D.J., Han Y. \& Wang L., 2015. Wood-plastic composite technology. Current Forestry Reports, Vol.1, pp.139-150.

Gulitah V. \& Liew K.C., 2018. Effect of plastic content ratio on the mechanical properties of wood-plastic composite (WPC) made from three different recycled plastic and acacia fibres. Transactions on Science and Technology, Vol.5, pp.184-189.

Jayaraman K. \& Bhattacharyya D., 2004. Mechanical performance of woodfibre-waste plastic composite materials. Resources, Conservation and Recycling, Vol.41, pp.307-319. https://doi.org/10.1016/j.resconrec.2003.12.001

Kartal S.N., Aysal S., Terzi E., Yılgör N., Yoshimura T. \& Tsunoda K., 2013. Wood and bamboo-PP composites: fungal and termite resistance, water absorption, and FT-IR analyses. BioResources, Vol.8, No.1, pp.1222-1244.

Kazemi-Najafi S. \& Englund K.R., 2013. Effect of highly degraded high-density polyethylene (HDPE) on processing and mechanical properties of wood flour-HDPE composites. Journal of Applied Polymer Science, Vol.129, pp.3404-3410. https://doi.org/10.1002/app.39021

Klyosov A. A., 2007. Wood-plastic composites. John Wiley \& Sons, Hoboken, New Jersey.

Lee S.H. \& Ohkita T., 2003. Mechanical and thermal flow properties of wood flour-biodegradable polymer composites. Journal of Applied Polymer Science, Vol.90, pp.1900-1905. https://doi.org/10.1002/app.12864

Najafi S.K., Hamidinia E. \& Tajvidi M., 2006. Mechanical properties of composites from sawdust and recycled plastics. Journal of Applied Polymer Science, Vol.100, pp.3641-3645. https://doi.org/10.1002/app.23159

Nourbakhsh A., Karegarfard A., Ashori A. \& Nourbakhsh A., 2010. Effects of particle size and coupling agent concentration on mechanical properties of particulate-filled polymer composites. Journal of Thermoplastic Composite Materials, Vol.23, No.2, pp.169-174. https://doi.org/10.1177/0892705709340962

Peltola H., Pääkkönen E., Jetsu P. \& Heinemann S., 2014. Wood based PLA and PP composites: Effect of fibre type and matrix polymer on fibre morphology, dispersion and composite properties. Composites Part A: Applied Science and Manufacturing, Vol.61, pp.13-22. https://doi.org/10.1016/j.compositesa.2014.02.002

Petchwattana N. \& Covavisaruch S., 2013. Effects of rice hull particle size and content on the mechanical properties and visual appearance of wood plastic composites prepared from poly (vinyl chloride). Journal of Bionic Engineering, Vol.10, pp.110-117. https://doi.org/10.1016/S1672-6529(13)60205-X

Poletto M., Dettenborn J., Zeni M. \& Zattera A.J., 2011. Characterization of composites based on expanded polystyrene wastes and wood flour. Waste Management, Vol.31, pp.779-784. doi: 10.1016/j.wasman.2010.10.027

Singh S. \& Mohanty A.K., 2007. Wood fiber reinforced bacterial bioplastic composites: Fabrication and performance evaluation. Composites Science and Technology, Vol.67, pp.1753-1763. https://doi.org/10.1016/j.compscitech.2006.11.009

\section{Biographical notes}

B. Latha Shankar has graduated in Industrial \& Production from Siddaganga Institute of Technology, Tumakuru, affiliated to Bangalore University, Bangalore, (Karnataka), India in 1991, acquired M.Sc (Engg) by Research from Visvesvaraya Technological University, Belagavi, (Karnataka), India in the year 2008 and received Ph.D. degree from Kuvempu University, Shimoga in Supply Chain Optimization. She has 5 years of industrial experience, 20 years of teaching experience 
and 9 years of experience in research. Currently she is serving as an Associate Professor in Industrial Engineering and Management department at Siddaganga institute of Technology, Tumkur, Karnataka, India. She has published 20 papers in National/International journals and presented 16 papers in conferences. She is also reviewer for three reputed international journals.

R. N. Darshan completed B.E in Mechanical Engineering from Siddaganga Institute of Technology, now pursuing M. Tech in Manufacturing Science and Engineering in the same institute. He has presented 2 research papers in national conferences and did one hobby project in final year B.E. entitled 'Solar distillation process to purify water through the solar energy'. Also he attended a workshop on mechanical integrated systems while doing M. Tech.

Sagar B. Sansuddi completed Diploma in Mechanical Engineering (DME) from Government Polytechnic Tumakuru in 2015 and BE in Mechanical from Siddaganga Institute of Technology in 2018. Currently, he is pursuing M.Tech in Manufacturing Science and Engineering in Siddaganga Institute of Technology. He has presented 2 research papers in national conferences and did one hobby project in final year B.E. entitled 'Development and fabrication of pneumatically operated robot arm for pick and place operations'. Also he attended a workshop on mechanical integrated systems while doing M. Tech.

S. Aditya completed B.E in Mechanical Engineering from RV Institute of Technology and completed MBA in the Cardiff University, now industrialist in Challakere and CEO of Prabitha Polymers, the manufacturers of synthetic wood, which is first in Karnataka having great theme of avoiding the deforestation and improving the afforestation.

Received March 2019

Accepted April 2020

Final acceptance in revised form April 2020 